\title{
Lipase Activity among Bacteria Isolated from Amazonian Soils
}

\author{
André Luis Willerding, ${ }^{1}$ Luiz Antonio de Oliveira, ${ }^{2}$ Francisco Wesen Moreira, ${ }^{2}$ \\ Mariana Gomes Germano, ${ }^{3}$ and Aloísio Freitas Chagas Jr. ${ }^{4}$ \\ ${ }^{1}$ Biochemistry and Molecular Biology Coordination, Amazon Biotechnology Center (CBA), Avnue Gov. Danilo Areosa, \\ 690 Distrito Industrial, 69075351 Manaus, AM, Brazil \\ ${ }^{2}$ Soil Microbiology Laboratory, National Research Institute of Amazonia (INPA), Caixa Postal 478, 69011-970 Manaus, AM, Brazil \\ ${ }^{3}$ Soils and Plant Tissue Laboratory, Brazilian Agricultural Research Corporation (EMBRAPA-SOY), Rod. Carlos João Strass, \\ Distrito de Warta, 86001-970 Londrina, PR, Brazil \\ ${ }^{4}$ Department of Agronomy, Federal University of Tocantins (UFTO), Rua Badeijós, Lote 07, Chácara 69/72, Zona Rural, \\ 77402-970 Gurupi, TO, Brazil
}

Correspondence should be addressed to André Luis Willerding, andre.cba@suframa.gov.br and

Luiz Antonio de Oliveira, luizoli@inpa.gov.br

Received 14 April 2011; Revised 27 July 2011; Accepted 27 July 2011

Academic Editor: Alane Beatriz Vermelho

Copyright () 2011 André Luis Willerding et al. This is an open access article distributed under the Creative Commons Attribution License, which permits unrestricted use, distribution, and reproduction in any medium, provided the original work is properly cited.

The objective of this study was to select lipase-producing bacteria collected from different counties of the Amazon region. Of the 440 bacteria strains, 181 were selected for the lipase assay in qualitative tests at Petri dishes, being 75 (41\%) lipase positive. The enzymatic index was determined during fifteen days at different temperatures $\left(30^{\circ}, 35^{\circ}, 40^{\circ}\right.$, and $\left.45^{\circ} \mathrm{C}\right)$. The highest lipase activity was observed within 72 hours at $30^{\circ} \mathrm{C}$. Twelve bacteria strains presented an index equal to or greater than the standard used like reference, demonstrating the potential of microbial resource. After the bioassay in Petri dishes, the selected bacteria strains were analyzed in quantitative tests on $p$-nitrophenyl palmitate ( $p$-NPP). A group of the strains was selected for other phases of study with the use in oleaginous substrates of the Amazonian flora, aiming for the application in processes like oil biotransformation.

\section{Introduction}

Lipase (triacylglycerol acylhydrolase E.C. 3.1.1.3) has an extensive industrial application by hydrolysing acyl ester bonds from acylglycerols at the interface between oil and water, acting also in the esterification and transesterification reactions [1-3]. Lipases are produced by many microorganisms. Most commercially useful lipases are of microbial origin. The increasing tendency of its market shows the importance to search new microbial resources to produce these enzymes $[4,5]$. Lipase-producing microorganisms have been found in different habitats such as industrial wastes, vegetable oil processing factories, dairies, soil contaminated with oil, oilseeds, and decaying food [6]. Lipase from different microorganisms presents different chemical characteristics, which may be useful for industries. A specific lipase activity of $P$. fluorescens S1K W1 was found in a medium which contained emulsified olive oil as carbon source. The enzyme showed a high lipolytic activity towards tricaproic $\left(\mathrm{C}_{6}\right)$ and tricaprylin $\left(\mathrm{C}_{8}\right)$ compared to the other triacylglycerols examined; also, it preferentially hydrolyzed the ester bonds in 1 and 3 of triolein [7]. Temperature and $\mathrm{pH}$ activity also may be different among lipases [8].

The environmental conditions of Amazon favor high metabolic activities and growth of several microorganisms. This microbial diversity may be useful to find new good enzymatic resources. The aim of this study was to evaluate the production of lipase from the collection of soil microorganisms from the National Institute for Amazon Research (INPA), aiming for the application in processes like oil biotransformation.

\section{Materials and Methods}

2.1. Organisms, Maintenance, and Culture Condition. The bacterial strains were obtained from the Soil Microorganisms Collection from the National Research Institute of Amazonia (INPA). The microorganisms were isolated from soils and 
roots of agricultural and forest environment as phosphatesolubilizing bacteria at specific phosphatase medium [9] in a research looking for this bacterial ability to be applied in low available phosphorus Amazonian soils. Stock cultures were started in basic medium containing glucose $(1.0 \%)$, yeast extract (0.2\%), $\mathrm{KH}_{2} \mathrm{PO}_{4} \quad(0.5 \%), \mathrm{MgSO}_{4} \quad(0.2 \%), \mathrm{CaCl}_{2}$ $(0.1 \%)$, and agar $(1.8 \%), \mathrm{pH} 6.5$, and incubated at $30^{\circ} \mathrm{C}$. For this study, 440 phosphate-solubilizing bacteria strains were tested for lipase activity. Strains that grew up to 72 hours were selected for lipase assay.

2.2. Lipase Production. The enzyme production was in an inducing medium $(\mathrm{pH} 8.0)$ containing olive oil $(2.0 \% \mathrm{v} / \mathrm{v})$, Tween $80(1.0 \% \mathrm{v} / \mathrm{v})$ and Rhodamine B $(0.001 \% \mathrm{w} / \mathrm{v})$, which makes easy the detection of the enzymatic activity, visualized by a halo close around the colonies [10-12]. Additionally, each Petri dish was subjected to UV irradiation (UV-A, $350 \eta \mathrm{m}$ ) mark model BIO-RAD UV Lamp 1660500. The enzymatic activity was measured by lipase activity index (LAI), a rate between the halo diameter close to the colony and the diameter of the colony during 15 days $[7,13$, 14], with five replicates. The activity was measured at four temperatures $\left(30^{\circ}, 35^{\circ}, 40^{\circ}\right.$, and $\left.45^{\circ} \mathrm{C}\right)$.

2.3. Quantitative Lipase Assay. The quantitative analysis was performed with bacterial strains that grew in basic medium up to 72 hours and incubated at $160 \mathrm{rpm}$ for $48 \mathrm{~h}$ at $30^{\circ} \mathrm{C}$ in shaken flasks. After 72 hours, an aliquot $(1000 \mu \mathrm{L})$ was transferred to $49 \mathrm{~mL}$ of the inducing liquid medium. After 72 hours, an aliquot $(2000 \mu \mathrm{L})$ was centrifuged at $12000 \mathrm{~g}$ for $20 \mathrm{~min}$ at $4^{\circ} \mathrm{C}$. The supernatant was used as the enzymatic crude extract. The activity was determined by $p$-nitrophenylpalmitate ( $p$-NPP) hydrolysis by spectrophotometer model UV Mini 1240 Shimadzu at $410 \eta \mathrm{m}$ [15]. An aliquot $(50 \mu \mathrm{L})$ from crude extract of each strain selected was added in $950 \mu \mathrm{L}$ of $p$-NPP solution containing $0.189 \mathrm{~g}$ of the substrate in $200 \mathrm{~mL}$ sodium acetate buffer $(\mathrm{pH} 8 ; 50 \mathrm{mM})$ added with 2,1\% Triton X-100 [16]. The effect of temperatures was studied (from 25 to $55^{\circ} \mathrm{C}$ ). The lipase activity was determined by the rate of $p$-nitrophenol production ( $p$-NP). One unit of enzyme activity was defined as the amount of lipase required to release one $\mu \mathrm{mol}$ of the $p$-NP. $\mathrm{min}^{-1}$.

\section{Results and Discussion}

From the 440 strains tested in the basic medium, 181 were chosen for testing lipase activity, since they presented a good preliminary development in that medium (up to 72 hours). From these, 75 strains (41\%) showed enzymatic activities (Table 1).

The ability of microorganisms to produce enzyme is influenced by environmental conditions such as temperature, $\mathrm{pH}$, and presence of inductors or repressors. Many experiments reported in the literature showed different times for analysis, varying from 1 hour to 120 hours in lipase qualitative assay $[6,7,13,14]$. Most of the bacteria tested in this study started lipase synthesis within 24 hours, but it was possible to observe the increase of the quantitative lipase activity until 72 hours, when occurred a declining
TABLE 1: Amount of lipolytic bacteria for each group analyzed.

\begin{tabular}{|c|c|c|c|c|c|}
\hline $\begin{array}{l}\text { Origin (city, } \\
\text { state) }\end{array}$ & Group & $\begin{array}{l}\text { No. of } \\
\text { strains }\end{array}$ & $\begin{array}{l}\text { Activated } \\
\text { strains }\end{array}$ & $\begin{array}{l}\text { Lipase } \\
\text { positive }\end{array}$ & $\%$ \\
\hline $\begin{array}{l}\text { (1) Acre (several } \\
\text { towns) }\end{array}$ & A & 4 & 1 & 1 & $100 \%$ \\
\hline $\begin{array}{l}\text { (2) Barreirinha } \\
\text { (AM) }\end{array}$ & $\mathrm{B}$ & 19 & 8 & 5 & $63 \%$ \\
\hline $\begin{array}{l}\text { (3) Rondônia } \\
\text { (several towns) }\end{array}$ & $\mathrm{D}$ & 11 & 2 & 0 & $0 \%$ \\
\hline $\begin{array}{l}\text { (4) Rio Preto da } \\
\text { Eva (AM) }\end{array}$ & $\mathrm{E}$ & 196 & 79 & 39 & $49 \%$ \\
\hline $\begin{array}{l}\text { (5) Manaus } \\
\text { (Brasileirinho) }\end{array}$ & M & 22 & 4 & 2 & $50 \%$ \\
\hline $\begin{array}{l}\text { (6) Projeto RECA } \\
\text { (RO) }\end{array}$ & $\mathrm{R}$ & 61 & 36 & 17 & $47 \%$ \\
\hline (7) Urucu (AM) & $\mathrm{U}$ & 86 & 42 & 10 & $24 \%$ \\
\hline \multirow[t]{2}{*}{$\begin{array}{l}\text { (8) Amazonas } \\
\text { (several towns) }\end{array}$} & $\mathrm{Z}$ & 41 & 9 & 1 & $11 \%$ \\
\hline & Total & 440 & 181 & 75 & $41 \%$ \\
\hline
\end{tabular}

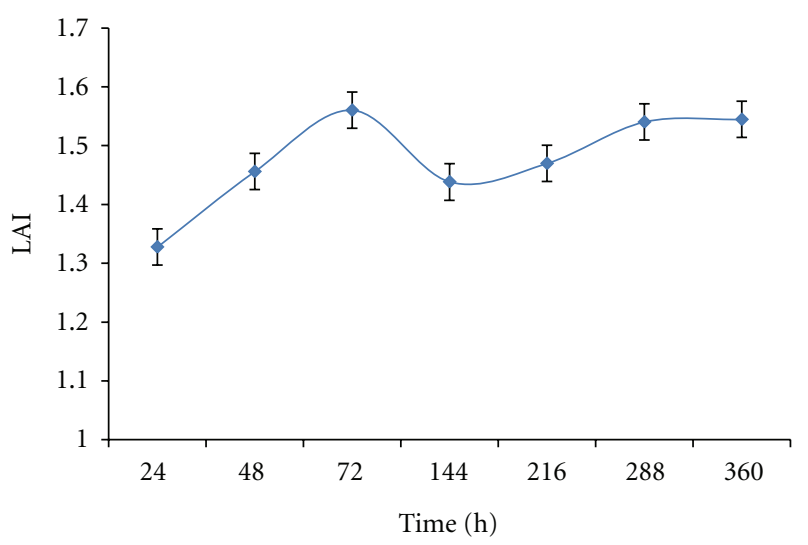

Figure 1: Evolution of the lipase activity index (LAI) in Petri dishes at $30^{\circ} \mathrm{C}$ (average of the 75 strains).

subsequently (Figure 1). These data corroborate with the literature, indicating this time for selecting bacteria.

The LAI analysed in each temperature at 72 hours decreased with the increase of temperature (Figure 2). Some bacteria had a different behavior but prevailed the highest averages at $30^{\circ} \mathrm{C}$. At this temperature, LAI increased linearly with the time, while, at higher temperatures, occurred a decline of the LAI values during the time of evaluation, with 48 hours being the best at $35^{\circ} \mathrm{C}$ and $45^{\circ} \mathrm{C}$ and 24 hours at $45^{\circ} \mathrm{C}$ (Figure 3).

In an overview, bacteria presented more lipase activity in lower temperatures, perhaps because their metabolisms accelerate when temperatures increases, resulting in depletions of enzymes activities faster. At $40^{\circ} \mathrm{C}$, the lipase production presents low variation, while, at $45^{\circ} \mathrm{C}$, the highest LAI occurred at 24 hours, with a strong decline after that.

This result is similar to the observed by Dong et al. [17] with Pseudomonas, which presented optimum lipase activity to Pseudomonas at $30^{\circ} \mathrm{C}$ for 72 hours at $\mathrm{pH}$ range 7-9. However, with Burkholderia sp., lipase activity was analyzed 


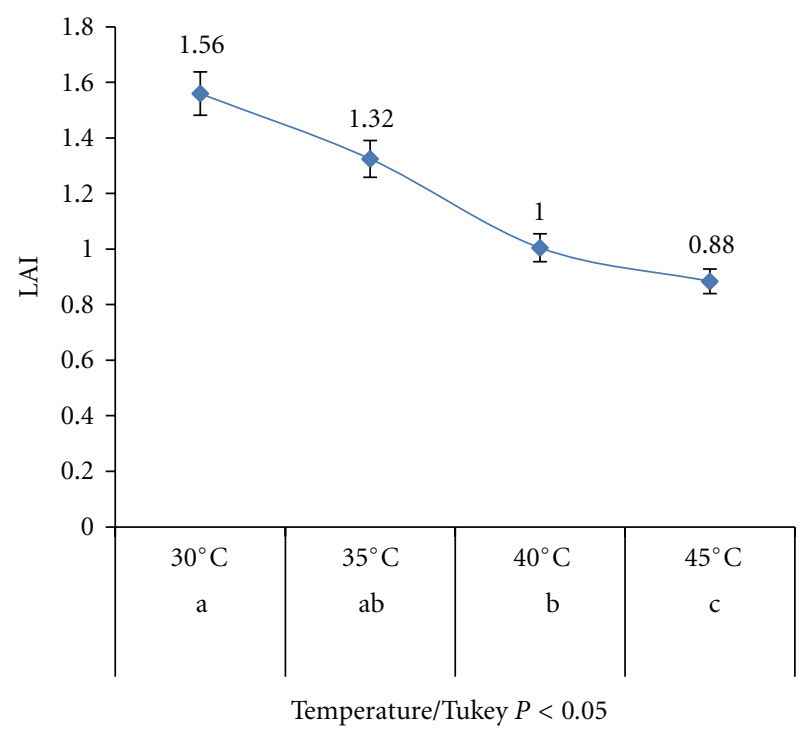

FIgURE 2: Lipase activity index (LAI) at different temperatures (average of the 75 strains).

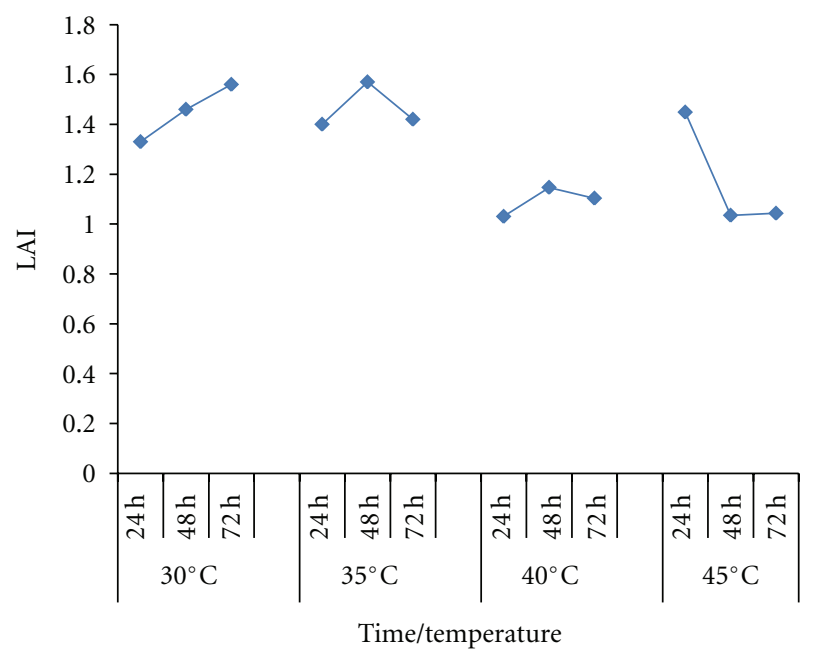

Figure 3: Lipase activity index (LAI) up to 72 hours at different temperatures (average of the 75 strains).

at a temperature range of $25-65^{\circ} \mathrm{C}$, and the highest lipase activity was obtained when the reaction was conducted at $55^{\circ} \mathrm{C}[18]$. Liu et al. [18] observed that the lipase response decreased when temperature increased, remaining 96, 92, 90 , and $78 \%$ of its original activity after being incubated at $25,37,42,5$, and $55^{\circ} \mathrm{C}$, respectively. This suggests that the Burkholderia was fairly stable during the temperature range examined. The lipases tested in this work appear to follow the same behavior.

When the application of microorganisms is wanted for industrial processes, the mechanisms of selection become important [4]. So, the analyzed parameters are decisive in screening. The highest average of the LAI happened at $30^{\circ} \mathrm{C}$ at 72 hours. The results corroborate with others reported, where the best lipase production occurred at $30^{\circ} \mathrm{C}[3,6$, 19, 20]. The lipase activity from Bacillus megaterium was

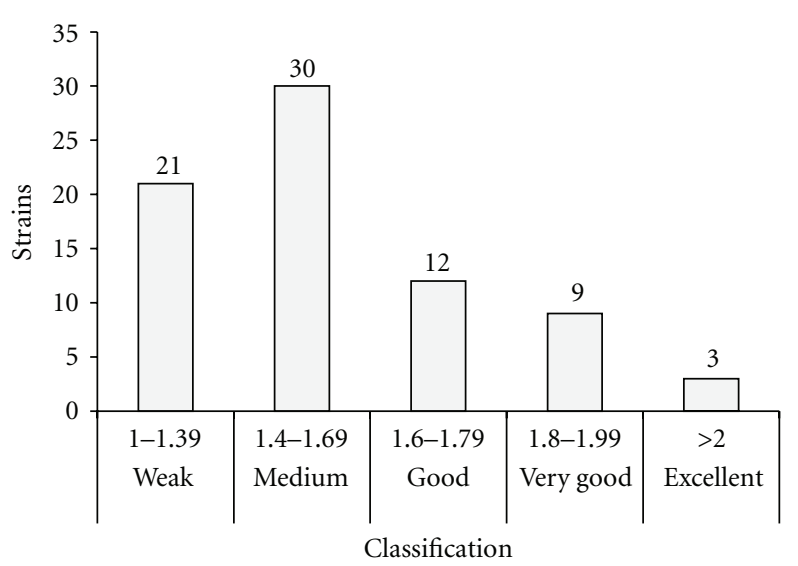

FIgURE 4: Classification of lipase activity index (LAI) for 75 strains after $72 \mathrm{~h}$ at $30^{\circ} \mathrm{C}$ in Petri dishes (olive culture).

analysed by Lima et al. [21] in the temperatures from 30 to $85^{\circ} \mathrm{C}$, with the peak occurring between $55^{\circ} \mathrm{C}$ and $65^{\circ} \mathrm{C}$, but they obtained good results at $29^{\circ} \mathrm{C}$. Snellman et al. [27], studying an extracellular lipase of Acinetobacter in $p$-NPP, observed a peak of activity at $55^{\circ} \mathrm{C}$, with the enzyme remaining activating up to $70^{\circ} \mathrm{C}$. The optimum temperature of reaction presented in this work is higher than the reported for many bacterial lipases under similar conditions' assay. Sharma et al. [6], studying the environmental influence on lipase production, observed that Lactobacillus plantarum had differentiated behaviour according to the change of temperature, where the lipase activity was analyzed from $22^{\circ} \mathrm{C}$ to $45^{\circ} \mathrm{C}$, with peak at $30^{\circ} \mathrm{C}$. Sant'Anna Jr. et al. [22] tested the productivity of the enzyme at $25^{\circ} \mathrm{C}, 30^{\circ} \mathrm{C}$, and $35^{\circ} \mathrm{C}$, with the best results at $30^{\circ} \mathrm{C}$. Stamford et al. [23] presented a process of screening lipolytic bacteria in vitro at $28^{\circ} \mathrm{C}$. George et al. [24] presented the best results at $37^{\circ} \mathrm{C}$. Sharma et al. [6] describe several works that present the best temperatures for the enzyme varying from $30^{\circ} \mathrm{C}$ to $60^{\circ} \mathrm{C}$.

After the definition of the ideal time and temperature, a classification was applied for the qualifying index, which revealed different levels of enzymatic activity, and it considers as reference, the strain Bacillus subtilis ATCC 6633 [23], that has a lipase enzymatic index of 1.80 (Figure 4 ). So, twelve bacteria presented a higher or similar index to the ATCC 6633. Nine bacteria were classified as "very good" and three as "excellent", which demonstrates the potential of the studied microbiota. However, all the bacteria with enzymatic index 1.60 and a high LAI were selected to quantitative tests, totalizing 24 bacteria strains. This screening took into account that bacteria which presented a medium classification in the tests in solid medium can present better results on $p$-NPP.

The behavior of 24 bacteria in the bioassay with different temperatures and $\mathrm{pHs}$ was similar to the average obtained with the 75 bacteria strains (Figure 5); there was also a highest activity at $30^{\circ} \mathrm{C}$ and $\mathrm{pH}$ 8.0. This information is important for lipase kinetic studies, when they must be tested in large scales of fermentation. The respective enzymatic indices for the 24 bacteria selected with LAI > 1.60 are in Table 2. 


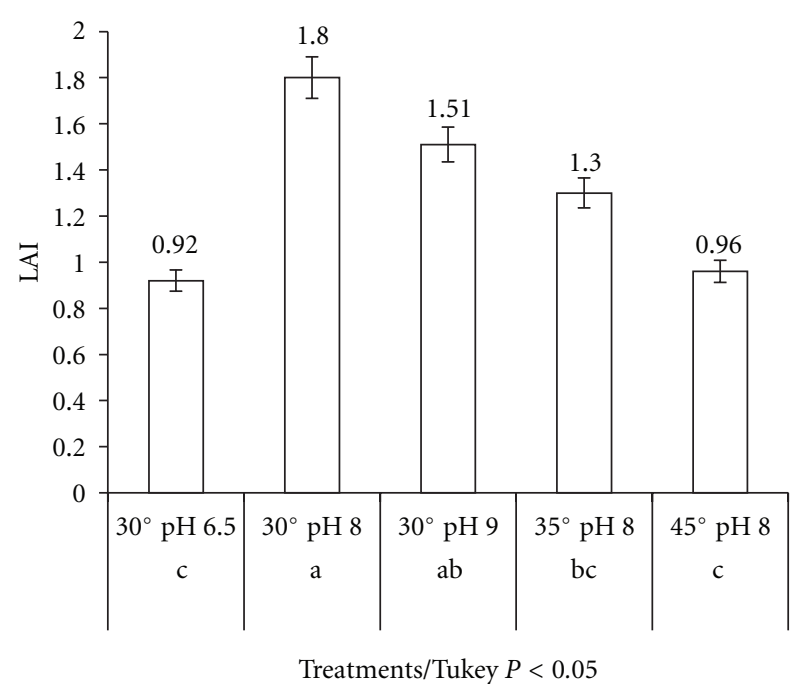

FIGURE 5: Classification of lipase activity index (LAI) for 25 strains at different treatments in Petri dishes (olive culture).

TABLE 2: Lipase activity index from selected strains on olive culture medium.

\begin{tabular}{lcccc}
\hline Origin & Bacteria strains & Average & SD & Tukey $(P<0.05)$ \\
\hline (1) INPA P-146 & E-089 & 2.41 & 0.05 & $\mathrm{a}$ \\
(2) INPA P-784 & U-053 & 2.20 & 0.32 & $\mathrm{ab}$ \\
(3) INPA P-697 & U-015 & 2.15 & 0.29 & $\mathrm{abc}$ \\
(4) INPA P-632 & R-024 & 1.98 & 0.21 & $\mathrm{abcd}$ \\
(5) INPA P-616 & R-016 & 1.95 & 0.16 & $\mathrm{abcd}$ \\
(6) INPA P-613 & R-048 & 1.97 & 0.26 & $\mathrm{abcd}$ \\
(7) INPA P-691 & U-027 & 1.93 & 0.20 & $\mathrm{abcd}$ \\
(8) INPA P-124 & E-170 & 1.89 & 0.18 & $\mathrm{bcd}$ \\
(9) INPA P-112 & E-005 & 1.81 & 0.13 & $\mathrm{bcd}$ \\
(10) INPA P-108 & E-100 & 1.81 & 0.15 & $\mathrm{bcd}$ \\
(11) INPA P-493 & E-139 & 1.80 & 0.25 & $\mathrm{bcd}$ \\
(12) INPA P-799 & U-068 & 1.80 & 0.28 & $\mathrm{bcd}$ \\
(13) INPA P-348 & Z-034 & 1.77 & 0.12 & $\mathrm{bcd}$ \\
(14) INPA P-478 & E-066 & 1.71 & 0.19 & $\mathrm{bcd}$ \\
(15) INPA P-423 & E-039 & 1.72 & 0.35 & $\mathrm{bcd}$ \\
(16) INPA P-803 & U-078 & 1.69 & 0.19 & $\mathrm{~cd}$ \\
(17) INPA P-798 & U-067 & 1.68 & 0.12 & $\mathrm{~cd}$ \\
(18) INPA P-093 & E-024 & 1.68 & 0.27 & $\mathrm{~cd}$ \\
(19) INPA P-082 & E-111 & 1.66 & 0.25 & $\mathrm{~cd}$ \\
(20) INPA P-117 & E-012 & 1.63 & 0.12 & $\mathrm{~d}$ \\
(21) INPA P-540 & E-087 & 1.62 & 0.09 & $\mathrm{~d}$ \\
(22) INPA P-106 & E-099 & 1.62 & 0.22 & $\mathrm{~d}$ \\
(23) INPA P-392 & E-053 & 1.61 & 0.17 & $\mathrm{~d}$ \\
(24) INPA P-593 & R-006 & 1.60 & 0.12 & $\mathrm{~d}$ \\
\hline & & & &
\end{tabular}

3.1. Lipase Activity. The lipases present different affinity for the substrate [24-26]. The activity varies in accordance with the chain length of the fat acids. So, some bacteria can present affinity to $p$-nitrophenylacetate $\left(C_{2}\right.$ small chains) or $p$-nitrophenycaprilate $\left(\mathrm{C}_{8}\right.$ medium chains). Other lipase isoforms present a better affinity for esters with long carbon

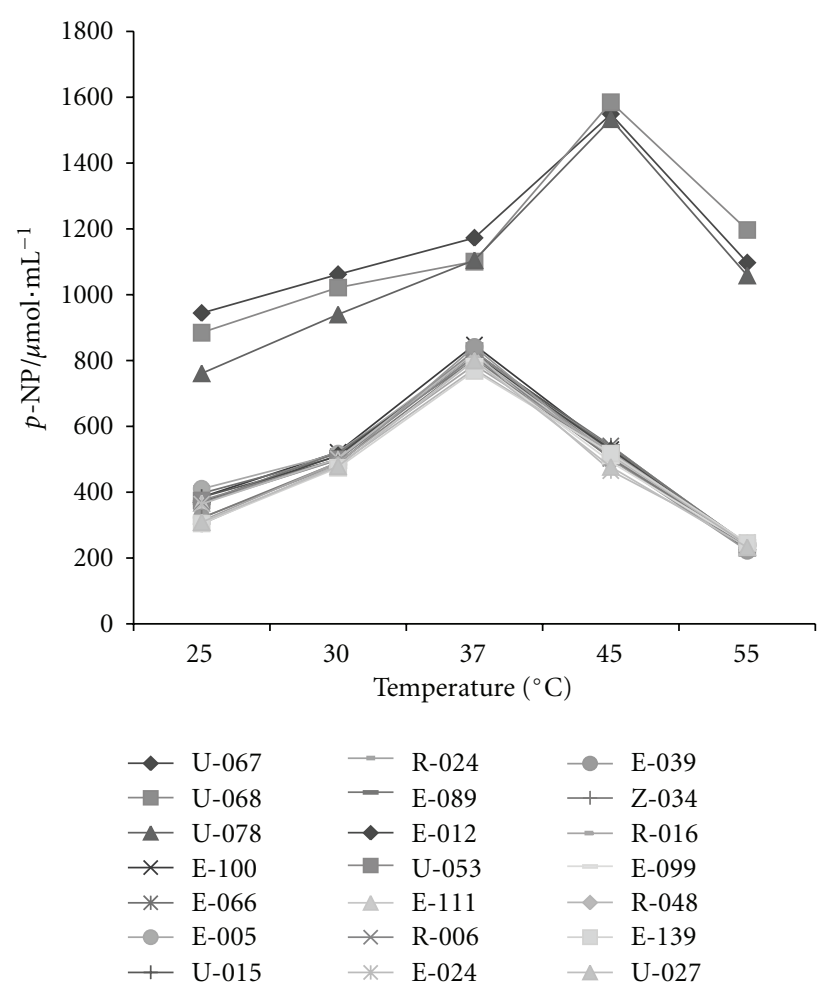

Figure 6: Effect of the temperature on lipase activity from crude extract on $p$-nitrophenylpalmitate (behavior of the 24 strains).

chain like $p$-nitrophenylaurate $\left(\mathrm{C}_{12}\right)$ or $p$-nitrophenylpalmitate $\left(\mathrm{C}_{16}\right)[6,7,17]$.

The lipase activity of the crude extracts solution of each strain selected was analyzed under $p$-NPP at different temperatures (Figure 6). The best lipase activity in the crude extract was at $45^{\circ} \mathrm{C}$ for the strains U-067, U-068, and U-078.

For all bacteria, the peak of activity occurred at $37^{\circ} \mathrm{C}$. These three bacteria were always superior to the rest in all test conditions. This suggests the highest affinity by lipase from these bacteria on the substrate $p$-NPP. When the peaks of the enzymatic activity are compared, the difference between the outstanding bacteria and other bacteria, at $37^{\circ} \mathrm{C}$, is the double. At $45^{\circ} \mathrm{C}$, the results become even 4 times bigger. The bacteria strains with the best results in this phase of the work were not those with the best results in the qualitative tests, where the analysis happened under agar medium with olive oil. Physical differences at these conditions can influence the lipase liberation. Even among the bacteria strains can be found isoforms enzymes that are differentiated by molecular weight, for example, and this may result in variation of migration in agar, but in broth culture these difficulties do not happen [27]. Though both substrates have long chains of carbon, oleic acid $\left(\mathrm{C}_{18}\right)$, the principal component of the olive oil, and $p$-NPP $\left(\mathrm{C}_{16}\right)$ are not the same thing. So, it is noticed that, for some bacteria, the lipase presented high affinity with the oil for others, the affinity was better with the $p$-NPP. Though they are in different assay conditions, the results presented the potential of the strains studied and indicate the group of 24 bacteria strains that was selected for other phases of study using oleaginous substrates of the 
Amazonian flora, aiming for the application in processes as oil biotransformation.

\section{References}

[1] K. E. Jaeger, S. Ransac, B. W. Dijkstra, C. Colson, M. Heuvel, and O. Misset, "Bacterial lipases," FEMS Microbiology Reviews, vol. 15, no. 1, pp. 29-63, 1994.

[2] M. G. Nascimento, P. R. C. Neto, and L. M. Mazzuco, "Biotransformação de óleos e gorduras," Biotecnologia Ciência \& Desenvolvimento, vol. 19, pp. 28-31, 2001.

[3] R. K. Saxena, A. Sheoran, B. Giri, and W. S. Davidson, "Purification strategies for microbial lipases," Journal of Microbiological Methods, vol. 52, no. 1, pp. 1-18, 2003.

[4] G. D. Haki and S. K. Rakshit, "Developments in industrially important thermostable enzymes: a review," Bioresource Technology, vol. 89, no. 1, pp. 17-34, 2003.

[5] M. M. D. Maia, M. M. C. Morais, M. A. Morais Jr., E. H. M. Melo, and J. L. Lima Filho, "Production of extracellular lipase by the phytopathogenic fungus Fusarium solani Fs1," Revista de Microbiologia, vol. 30, no. 4, pp. 304-309, 1999.

[6] R. Sharma, Y. Chisti, and U. C. Banerjee, "Production, purification, characterization, and applications of lipases," Biotechnology Advances, vol. 19, no. 8, pp. 627-662, 2001.

[7] G. N. Silva Filho and C. Vidor, "Solubilização de fosfatos por microrganismos na presença de fontes de carbono," Revista Brasileira de Ciência do Solo, vol. 24, pp. 311-319, 2000.

[8] H. Wang, R. Liu, F. Lu, W. Qi, J. Shao, and H. Ma, "A novel alkaline and low-temperature lipase of Burkholderia cepacia isolated from Bohai in China for detergent formulation," Annals of Microbiology, vol. 59, no. 1, pp. 105-110, 2009.

[9] C. Sylvester-Bradley, N. Asaka, L. M. S. Torraca, F. M. M. Magalhães, L. A. Oliveira, and R. M. Pereira, "Levantamento quantitativo de microrganismos solubilizadores de fosfato na rizosfera de gramíneas e leguminosas forrageiras na Amazônia," Acta Amazônica, vol. 12, no. 1, pp. 15-22, 1982.

[10] H. F. Castro, A. A. Mendes, and J. C. Santos, "Modificação de óleos e gorduras por biotransformação," Quimica Nova, vol. 27, no. 1, pp. 146-156, 2004.

[11] T. Ito, H. Kikuta, E. Nagamori et al., "Lipase production in two-step fed-batch culture of organic solvent-tolerant Pseudomonas aeruginosa LST-03," Journal of Bioscience and Bioengineering, vol. 91, no. 3, pp. 245-250, 2001.

[12] K. E. Jaeger and G. Kouker, "Specific and sensitive plate assay for bacterial lipases," Applied and Environmental Microbiology, vol. 53, no. 1, pp. 211-213, 1987.

[13] G. M. Chaves, M. A. Cavalcanti, and A. L. F. Porto, "Pathogenicity characteristics of stocked and fresh yeasts strains," Brazilian Journal of Microbiology, vol. 34, no. 3, pp. 197-202, 2003.

[14] R. Sharma, S. Soni, R. Vohra, L. Gupta, and J. Gupta, "Purification and characterisation of a thermostable alkaline lipase from a new thermophilic Bacillus sp. RSJ-1," Process Biochemistry, vol. 37, no. 10, pp. 1075-1084, 2002.

[15] U. Winkler and M. Stuckmann, "Glycogen, hyaluronate, and some other polysaccharides greatly enhance the formation of exolipase by Serratia marcescens," Journal of Bacteriology, vol. 138, no. 3, pp. 663-670, 1979.

[16] G. M. Pastore, V. S. R. Costa, and M. G. B. Koblitz, "Purificação parcial e caracterização bioquímica de lipase extracelular produzida por nova linhagem de Rhizopus sp," Ciência e Tecnologia de Alimentos, vol. 23, no. 2, pp. 135-140, 2003.

[17] H. Dong, S. Gao, S. Han, and S. Cao, "Purification and characterization of a Pseudomonas sp. lipase and its properties in non-aqueous media," Biotechnology and Applied Biochemistry, vol. 30, no. 3, pp. 251-256, 1999.

[18] C. H. Liu, W. B. Lu, and J. S. Chang, "Optimizing lipase production of Burkholderia sp. by response surface methodology," Process Biochemistry, vol. 41, no. 9, pp. 1940-1944, 2006.

[19] C. Hemachander, N. Bose, and R. Puvanakrishan, "Whole cell immobilization of Ralstonia picketii for lipase production," Process Biochemistry, vol. 36, pp. 629-633, 2001.

[20] A. Ionitã, M. Moscovici, A. Drãgoloci et al., "Lipase production in discontinous operation system using a Candida lipolytica strain," Romanian Biotechnological Letters, vol. 7, no. 1, pp. 547-552, 2001.

[21] V. M. G. Lima, N. Krieger, M. I. M. Sarquis, D. A. Mitchell, L. P. Ramos, and J. D. Fontana, "Effect of nitrogen and carbon sources on lipase production by Penicillium aurantiogriseum," Food Technology and Biotechnology, vol. 41, no. 2, pp. 105-110, 2003.

[22] Sant'Anna Jr., D. M. G. Freire, P. M. Gomes, and E. P. S. Bon, "Lipase production by a new proming strain of Penicillium restrictum," Revista de Microbiologia, vol. 28, no. 1, pp. 6-12, 1997.

[23] T. M. Stamford, J. M. Araujo, and N. P. Stamford, "Atividade enzimática de microrganismos isolados do jacatupé (Pachyrhizus erosus L. Urban)," Ciência e Tecnologia de Alimentos, vol. 18, no. 4, pp. 1-10, 1998.

[24] E. George, C. Tamerler, A. Martinez, M. J. Martinez, and T. Keshavarz, "Influence of growth medium composition on the lipolytic enzyme activity of Ophiostoma piliferum (Cartapip)," Journal of Chemical Technology and Biotechnology, vol. 74, no. 2, pp. 137-140, 1999.

[25] R. Gupta, P. Rathi, N. Gupta, and S. Bradoo, "Lipase assays for conventional and molecular screening: an overview," Biotechnology and Applied Biochemistry, vol. 37, no. 1, pp. 63-71, 2003.

[26] E. Haba, O. Bresco, C. Ferrer, A. Marqués, M. Busquets, and A. Manresa, "Isolation of lipase-secreting bacteria by deploying used frying oil as selective substrate," Enzyme and Microbial Technology, vol. 26, no. 1, pp. 40-44, 2000.

[27] E. A. Snellman, E. R. Sullivan, and R. R. Colwell, "Purification and properties of the extracellular lipase, LipA, of Acinetobacter sp. RAG-1," European Journal of Biochemistry, vol. 269, no. 23, pp. 5771-5779, 2002. 

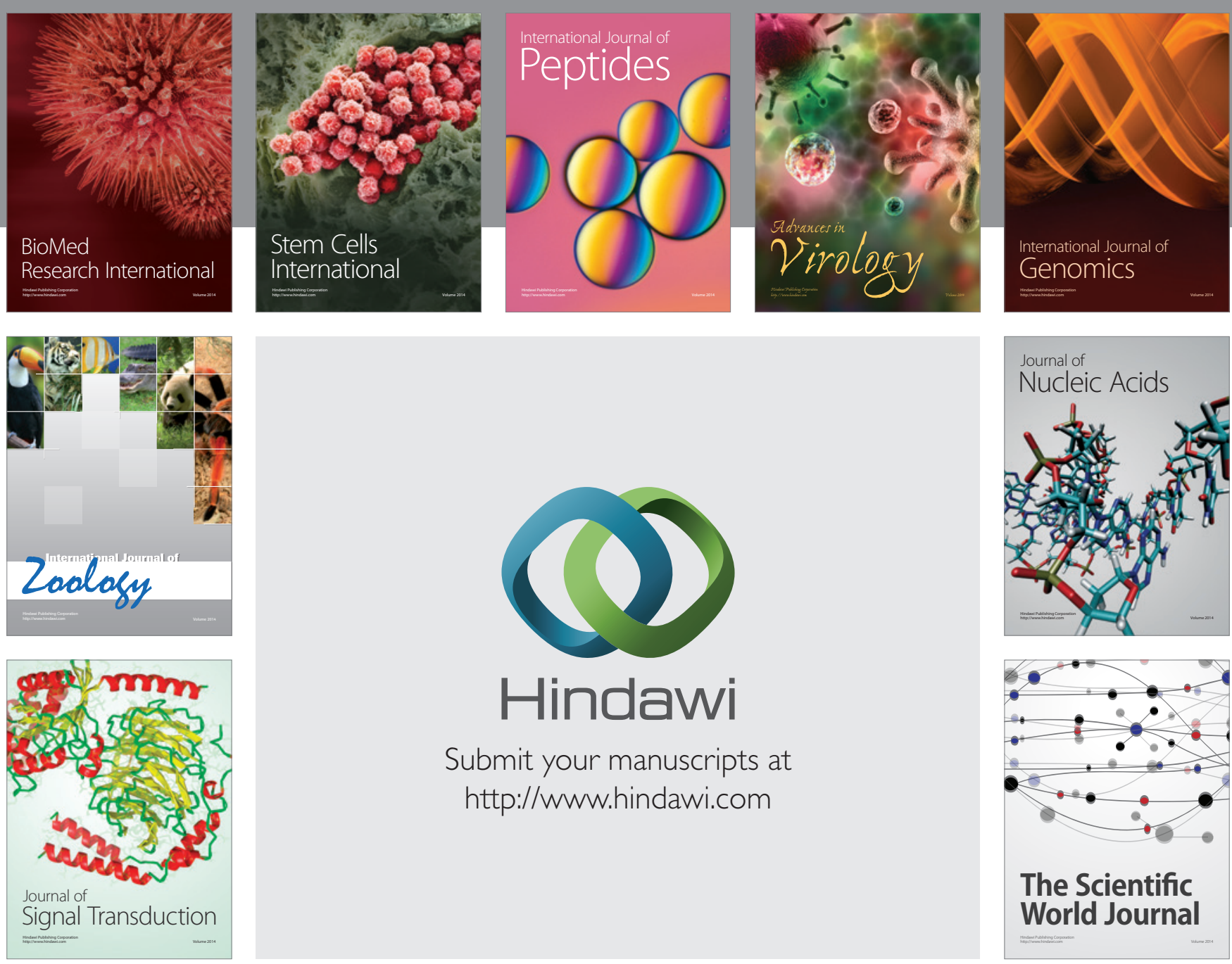

Submit your manuscripts at

http://www.hindawi.com
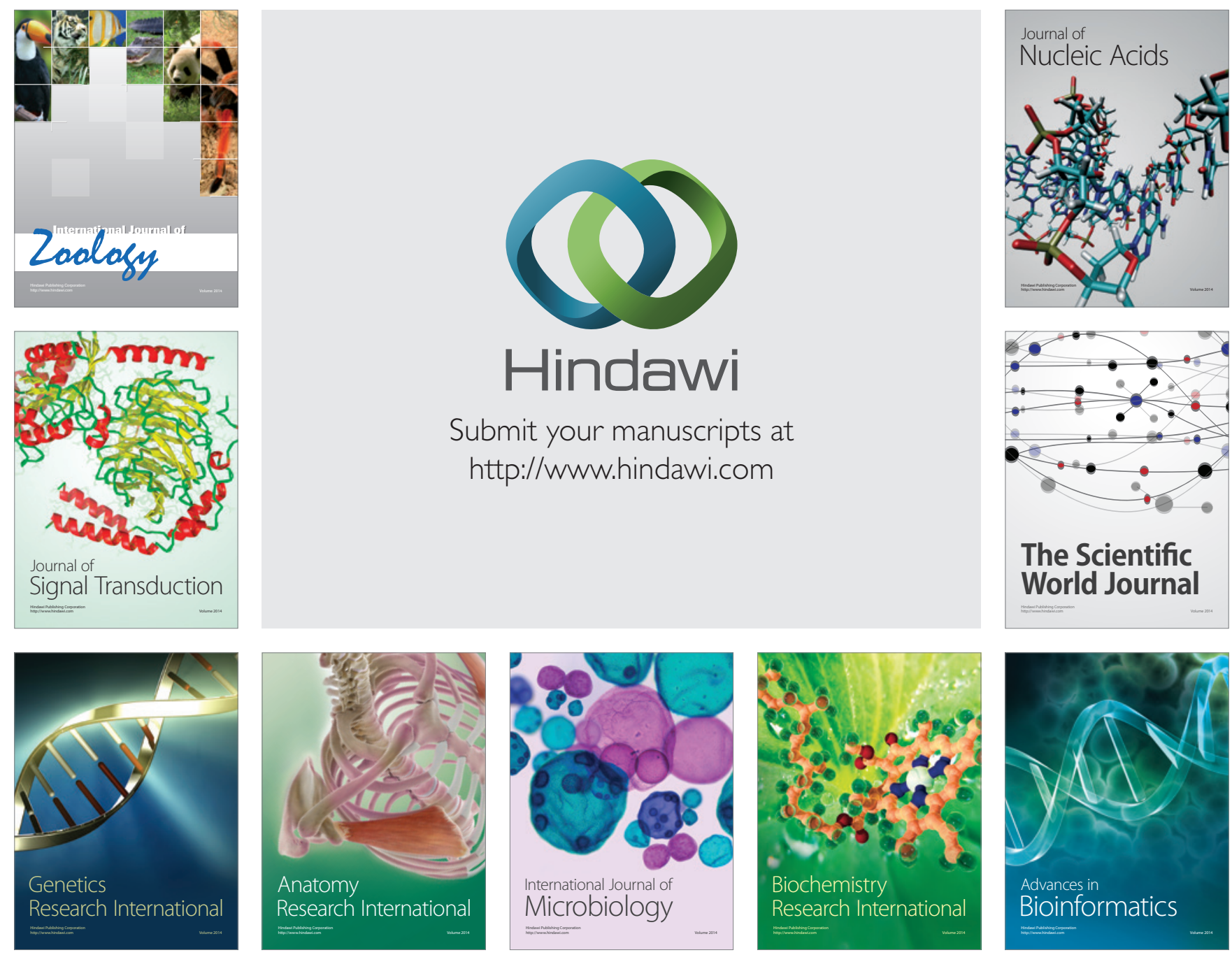

The Scientific World Journal
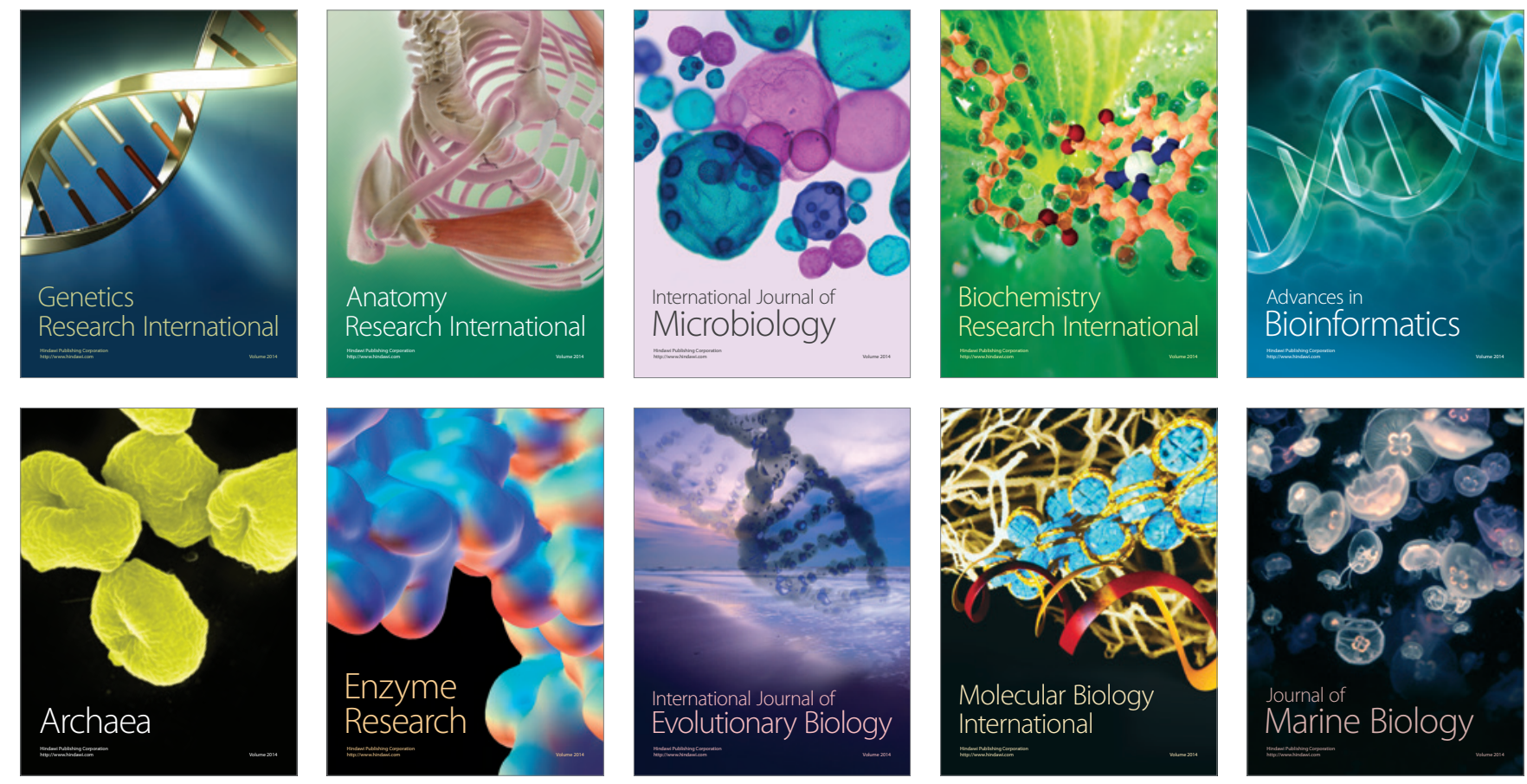